ORIGINAL ARTICLE

\title{
Incidence by occupation and industry of acute work related respiratory diseases in the UK, 1992-2001
}

\author{
J C McDonald, Y Chen, C Zekveld, N M Cherry
}

Occup Environ Med 2005;62:836-842. doi: 10.1136/oem.2004.019489

See end of article for authors' affiliations

Correspondence to: Professor J C McDonald, Imperial College School of Medicine, National Heart \& Lung Institute, Occupational and

Environmental Medicine, Dovehouse Street, London SW3 6LY, UK;

c.mcdonald@

imperial.ac.uk

Accepted 18 May 2005

\begin{abstract}
Aims: To summarise incidence rates and epidemiological characteristics of new cases of work related respiratory disease reported by specialist physicians in thoracic and occupational medicine, with particular reference to occupation, industry, and causal agents for asthma, inhalation accidents, and allergic alveolitis.

Methods: Cases reported 1992-2001 to the SWORD and OPRA national surveillance schemes, in which almost all UK chest and occupational physicians participate, were analysed by age, sex, cause, occupation, and industry, with incidence rates calculated against appropriate denominators.

Results: Excluding diseases of long latency, infrequently seen by occupational physicians, the distribution of diagnoses in the two specialties was similar, but with rates generally much higher in occupational than chest physicians. Occupational asthma was responsible for about $25 \%$ of cases overall, affecting mainly craft related occupations and machinists, and most often attributed to isocyanates, metals, grains, wood dusts, solders, and welding fume. These same occupations were those at highest risk from inhalation injuries, most frequently caused by irritant gases, vapours, and fume. Among medical technicians and nurses, however, glutaraldehyde and latex were the main causes of occupational asthma. Allergic alveolitis was seldom reported, with almost all cases in agriculture, forestry, and fishing.

Conclusion: During the 10 year period studied, there were few changes in level of reported incidence, apart from some decline in occupational asthma and inhalation injuries. These results and their implications should be distinguished from much higher estimates of asthma made worse by work derived from population surveys, based on prevalence rather than incidence, and self-reported symptoms rather than diagnoses made by specialist physicians. Even so, the reported incidence of new cases of acute respiratory illness caused by work remains substantial.
\end{abstract}

$\mathrm{T}$ he UK has a unique system of occupational disease surveillance. Thanks to the joint interest of the British Thoracic Society (BTS) and Society of Occupational Medicine (SOM) in having better information on occupational asthma, a reporting scheme, later known as SWORD (Surveillance of Work-related and Occupational Respiratory Disease), was initiated at the National Heart and Lung Institute in London at the end of 1988. ${ }^{1}$ This scheme, now in its sixteenth year, is based on the voluntary submission of monthly reports of all newly diagnosed cases of occupational respiratory illness which, in the opinion of specialist chest and occupational physicians, are caused by work. Brief details are requested on age, sex, postcode, diagnosis, industry, occupation, and suspected agent, but neither patient's name nor employer are reported. Guidelines to all participants require that the occupation (job) reported should refer to the type of work at the time of exposure to the suspected agent, not necessarily the present job. In identifying the industrial category, a description in as specific terms as possible is requested, rather than by reference to a code.

Early success of SWORD led to the establishment of closely similar reporting schemes first, in 1993, for skin disease by dermatologists and then, in 1996, for infectious diseases by communicable disease consultants and for all types of work related illness by occupational physicians. Later, three other schemes were added: for hearing, musculoskeletal, and mental illnesses, by the relevant specialists. These seven schemes, collectively known as ODIN (Occupational Disease Intelligence Network) were, from 1996 onwards, administered by the university Centre for Occupational and Environmental Health in Manchester, and replaced at the end of 2001 by a similar but new scheme (THOR).

\section{DEVELOPMENT}

The first full year of the SWORD scheme in 1989 was largely concerned with recruitment of BTS and SOM participants, and the improvement of reporting procedures. During the first three years, 1989-91, 776 doctors participated, equally divided between occupational physicians (391) and chest consultants (385), the latter including at least one physician in $90 \%$ of the UK's chest clinics. ${ }^{1}$ In anticipation of a possible decline from the initial enthusiasm, it was decided in January 1992 to divide the chest physicians into two groups: a "core" of 32 doctors known to have a special interest in occupational respiratory disease, and the remainder into 12 random samples, each of around 30. The core members continued to report all eligible cases monthly, and the remainder for one month a year only. This virtually doubled the estimated incidence of reported disease, a level which has since been maintained. The procedure for occupational physicians remained unchanged (that is, without sampling) until 1996, when they began to report all types of work related disease. At this point, a much larger number of occupational physicians (almost 800) agreed to participate in a separate scheme, OPRA (Occupational Physicians Reporting Activity), and monthly random sampling was introduced for them all. ${ }^{3}$ This paper will deal only with data obtained for the 10 year period, 1992-2001, the period since the introduction of

Abbreviations: BTS, British Thoracic Society; LFS, Labour Force Survey; ODIN, Occupational Disease Intelligence Network; OPRA, Occupational Physicians Reporting Activity; SIC, Standard Industrial Classification; SOC, Standard Occupational Classification; SOM, Society of Occupational Medicine; SWORD, Surveillance of Work-related and Occupational Respiratory Disease 
sampling for the chest physicians. Schemes which require voluntary participation, however, are inevitably subject to some annual fluctuation in level of reporting. Thus the total number of cases actually reported by all chest physicians (core and other) each year 1992-2001 varied from 888 to 1095 (median 1019), and the estimated total, based on sampling, from 2046 to 3597 (median 2863). Low values, in 1995 and 1996, prompted efforts to encourage reporting, and resulted in the numbers of actual and estimated cases returning to their former level.

\section{OBJECTIVES}

The purpose of the present paper is to summarise information on the incidence of work related respiratory disease from the SWORD and OPRA schemes, obtained during the 10 year period 1992-2001. As contemporary denominators are clearly inappropriate for diseases of long latency, analyses of such diseases, made previously using census data, ${ }^{2}$ have not been repeated. Estimated incidence rates in this paper are for three specific disease categories of short latency: occupational asthma, allergic alveolitis, and illness caused by inhalation accidents, and focus on industry, occupation, and the suspected agents.

\section{MATERIALS AND METHODS Denominators}

As almost all the chest physicians in the UK are SWORD participants, the national Labour Force Survey (LFS) of all people in full or part time employment provides an appropriate denominator for the calculation of specific countrywide incidence rates. The LFS is a sample survey of the UK population carried out every three months. Although relatively minor changes in employment continually occur, it was decided that for the present analyses, LFS data for the winter of $1999^{4}$ were appropriate, being as close as possible to 2001, when a separate denominator for occupational physicians became available. Only a small proportion (12\%) of all employees are served by occupational physicians however, and no suitable denominator existed for them until 2001, when a special postal survey was undertaken. ${ }^{5}$ In this survey, active participants were asked to estimate the number of full or part time employees for whom they currently provided occupational health care, and to cross tabulate the data by sex, occupation, and industry. Age distributions were not requested. As in the other ODIN schemes, occupation and industry were coded using the Standard Occupational
Classification $(\mathrm{SOC})^{6}$ and the Standard Industrial Classification (SIC). ${ }^{7}$ To facilitate this task, the occupational physicians were supplied with lists of SOC and SIC two digit codes with definitions. These lists can be obtained from the authors on request.

\section{Case reports}

During the 10 year period, 1992-2001, the estimated number of new cases of work related respiratory disease reported to SWORD by chest physicians was 27 952. Of these, 8644 were reported by the "core" group of chest physicians and the remaining 19308 estimated from the monthly samples.

The methods used have been described more fully elsewhere. ${ }^{2}$ During the same period, the corresponding total estimate based on occupational physicians' reports was 5983, of which 4344 were obtained by sampling. As these two data sets are quite independent, with little evidence of overlap, and deal with illnesses of differing severity and industrial provenance, their analyses have also been kept separate.

The estimated average annual incidence of disease by age, sex, and diagnosis in the two groups, with rates per million based on appropriate denominators, is shown by diagnosis in table 1. Two thirds of all cases reported by chest physicians were diseases of long latency, compared with less than one third reported by occupational physicians, who seldom see employees after retirement. The average annual rates of necessity present the same pattern, although because the denominator for the occupational physicians is much the smaller, their rates tend to be higher; in some illnesses (for example inhalation injuries and asthma) much higher. This is in contrast to allergic alveolitis, where almost all cases were reported by chest physicians. Average annual incidence rates based on chest physician reports for these two diagnoses are shown in table 2 by age and sex. In males, asthma rates increased with age. Both asthma and inhalation injuries were appreciably more frequent in men than in women. Incidence rates based on occupational physician reports were also much higher in men than in women, but the effect of age could not be studied, as this was not recorded in the relevant denominator.

\section{Analyses}

As information on occupation (that is, job) was coded for the whole of the 10 year period under review, the basic analyses of average estimated annual incidence in nine occupational groups are dealt with first (see table 3 ). Coding by industry in eight groups has been undertaken only since 1996; the rates

Table 1 Estimated average annual incidence rates of work related respiratory disease reported by chest and occupational physicians, UK, 1992-2001

\begin{tabular}{|c|c|c|c|c|c|c|}
\hline \multirow[b]{2}{*}{ Disease } & \multicolumn{3}{|c|}{ Chest physicians } & \multicolumn{3}{|c|}{ Occupational physicians } \\
\hline & $\begin{array}{l}\text { Estimated } \\
\text { total annual } \\
\text { cases* }^{*}\end{array}$ & (\%) & $\begin{array}{l}\text { Average } \\
\text { annual rate/ } \\
\text { milliont }\end{array}$ & $\begin{array}{l}\text { Estimated total } \\
\text { annual cases* }\end{array}$ & (\%) & $\begin{array}{l}\text { Average } \\
\text { annual rate/ } \\
\text { million } \ddagger\end{array}$ \\
\hline Allergic alveolitis & 50 & (1.8) & 2 & 4 & $(0.7)$ & 1 \\
\hline Asthma & 616 & $(22.0)$ & 22 & 281 & (47.0) & 87 \\
\hline Benign pleural disease & 752 & $(26.9)$ & 27 & 18 & $(3.0)$ & 6 \\
\hline Bronchitis & 55 & (2.0) & 2 & 14 & (2.3) & 4 \\
\hline Infections & 45 & (1.6) & 2 & 15 & $(2.5)$ & 5 \\
\hline Inhalation accidents & 98 & (3.5) & 4 & 116 & (19.4) & 36 \\
\hline Lung cancer & 104 & (3.7) & 4 & 2 & $(0.3)$ & 1 \\
\hline Mesothelioma & 733 & (26.2) & 27 & 21 & (3.5) & 7 \\
\hline Pneumoconiosis & 282 & (10.1) & 10 & 20 & (3.3) & 6 \\
\hline Other & 60 & (2.1) & 2 & 108 & (18.1) & 34 \\
\hline Total & 2795 & $(100)$ & 101 & 598 & $(100)$ & 186 \\
\hline
\end{tabular}

*Estimated from monthly samples; see text.

†Based on the national Labour Force Survey.

‡Based on estimated employees served by occupational physicians. 
Table 2 Estimated average annual incidence and rates, by age and sex, of occupational asthma and inhalation accidents reported by chest physicians, UK, 1992-2001

\begin{tabular}{|c|c|c|c|c|c|c|c|c|}
\hline \multirow[b]{3}{*}{$\begin{array}{l}\text { Age group } \\
\text { (years) }\end{array}$} & \multicolumn{4}{|c|}{ Occupational asthma } & \multicolumn{4}{|c|}{ Inhalation accidents } \\
\hline & \multicolumn{2}{|l|}{ Males } & \multicolumn{2}{|c|}{ Females } & \multicolumn{2}{|l|}{ Males } & \multicolumn{2}{|c|}{ Females } \\
\hline & $\begin{array}{l}\text { Cases } \\
\text { (n) }\end{array}$ & Rate/million & $\begin{array}{l}\text { Cases } \\
\text { (n) }\end{array}$ & Rate/million & $\begin{array}{l}\text { Cases } \\
\text { (n) }\end{array}$ & Rate/million & $\begin{array}{l}\text { Cases } \\
\text { (n) }\end{array}$ & Rate/million \\
\hline $16-30$ & 30 & 20 & 42 & 13 & 13 & 3 & 3 & 1 \\
\hline $31-45$ & 154 & 26 & 66 & 14 & 33 & 6 & 5 & 1 \\
\hline $46-60$ & 145 & 33 & 57 & 15 & 27 & 6 & 7 & 2 \\
\hline $60+$ & 41 & 43 & 7 & 13 & 5 & 5 & 0 & 1 \\
\hline Total* & 429 & 28 & 175 & 14 & 83 & 5 & 15 & 1 \\
\hline
\end{tabular}

shown in table 4 are therefore based on the six year period 1996-2001, when the rates for asthma were on average somewhat lower. The 77 occupations and 60 types of industry identified by a second digit in these broad categories were summarised in the earlier paper on denominators. ${ }^{5}$

\section{OCCUPATIONAL ASTHMA}

\section{Incidence}

It can be seen in table 3 that by far the highest reported rates of asthma by both chest and occupational physicians were in craft and related occupations, followed by plant and machine operatives, and associated professional and technical workers. Overall, the rates were some four times higher when based on cases reported by occupational physicians than by chest physicians; this difference was seen particularly for associate professional and technical jobs, and for employees in personal and protective services. The analyses of asthma by industry presented in table 4 show rates generally higher in primary and manufacturing industries, but much lower in utilities, construction, and the health and social services. Insight into the complex relation of job and industry is provided by consideration of the specific causal agents typical of various types of work.

\section{Agents}

During the 10 year period well over 100 agents were reported by chest physicians as having caused occupational asthma, but many were compounds or mixtures with possibility of overlap. Those classified in table 5 fell into four main groups, the largest of which were organic $(35 \%)$ or chemical $(32 \%)$, followed by two smaller groups: metallic (7\%), miscellaneous (17\%); 9\% were unknown/unspecified. Isocyanates were incriminated in $14 \%$ of all cases, flour or grain in $9 \%$, and wood dust in 6\%; metallic agents, solder/colophony, resins, and glutaraldehyde were also of note. The annual average number of cases of occupational asthma fell from 703 in 1992-1995 to 559 in 1996-2001, explained mainly by the decreased reporting of almost all agents in the chemical, metallic, and miscellaneous categories, but only by flour/ grain, solder/colophony, and laboratory animals in the organic group.

The distribution of the 15 agents most frequently reported by chest physicians is set out in table 6 by occupation and industry, with 10 or more cases per annum shown in bold. The pattern by occupation is reasonably clear in that, with few exceptions, there were high numbers only among craft related and plant and machine operators, and then only for a limited number of agents. Isocyanates and metals are prominent in both groups, but with the addition of flour/ grain, wood dusts, solder/colophony, and welding fume in the craft related occupations. Also prominent are the specific associations between glutaraldehyde and latex, the health and social services, and technical and associate professional occupations, the latter being mainly nursing. There is a less clear relation between industry and exposures, but agents such as isocyanates, metals, and solder/colophony are those that occur in manufacture of metals/automotive products. It is evident, too, that exposure to almost all of the more common agents, particularly isocyanates and wood dusts, occurred in "all other industries".

\begin{tabular}{|c|c|c|c|c|c|c|c|c|}
\hline \multirow[b]{3}{*}{ Occupation } & \multicolumn{4}{|c|}{ Asthma } & \multicolumn{4}{|c|}{ Inhalation accidents } \\
\hline & \multicolumn{2}{|c|}{$\begin{array}{l}\text { Chest } \\
\text { physicians }\end{array}$} & \multicolumn{2}{|c|}{$\begin{array}{l}\text { Occupational } \\
\text { physicians }\end{array}$} & \multicolumn{2}{|c|}{$\begin{array}{l}\text { Chest } \\
\text { physicians }\end{array}$} & \multicolumn{2}{|c|}{$\begin{array}{l}\text { Occupational } \\
\text { physicians }\end{array}$} \\
\hline & $\mathbf{n}$ & Rate & $\mathbf{n}$ & Rate & $\mathbf{n}$ & Rate & $\mathbf{n}$ & Rate \\
\hline 1. Managers \& administrators & 17 & 4 & 5 & 20 & 1 & $<0.5$ & 1 & 2 \\
\hline 2. Professional & 22 & 7 & 19 & 27 & $<0.5$ & $<0.5$ & 7 & 10 \\
\hline $\begin{array}{l}\text { 3. Associated professional \& } \\
\text { technical }\end{array}$ & 55 & 19 & 50 & 161 & 3 & 1 & 15 & 48 \\
\hline 4. Clerical \& secretarial & 15 & 4 & 10 & 27 & 4 & 1 & 3 & 8 \\
\hline 5. Craft \& related & 257 & 78 & 81 & 455 & 13 & 4 & 26 & 148 \\
\hline 6. Personal \& protective services & 22 & 7 & 17 & 67 & 5 & 2 & 12 & 45 \\
\hline 7. Sales & 5 & 2 & 3 & 14 & $<0.5$ & $<0.5$ & 0 & 0 \\
\hline 8. Plant \& machine operatives & 166 & 66 & 69 & 180 & 24 & 10 & 29 & 74 \\
\hline 9. Other & 46 & 22 & 26 & 44 & 19 & 9 & 10 & 17 \\
\hline 10. Not known & 12 & - & 2 & - & 30 & - & 14 & - \\
\hline Total & 616 & 22 & 281 & 87 & 98 & 4 & 116 & 36 \\
\hline
\end{tabular}


Table 4 Estimated average annual incidence and rates/million* of selected disease by industry, 1996-2001

\begin{tabular}{|c|c|c|c|c|c|c|c|c|}
\hline \multirow[b]{3}{*}{ Industry } & \multicolumn{4}{|c|}{ Asthma } & \multicolumn{4}{|c|}{ Inhalation accidents } \\
\hline & \multicolumn{2}{|c|}{ Chest physicians } & \multicolumn{2}{|c|}{$\begin{array}{l}\text { Occupational } \\
\text { physicians }\end{array}$} & \multicolumn{2}{|c|}{ Chest physicians } & \multicolumn{2}{|c|}{$\begin{array}{l}\text { Occupational } \\
\text { physicians }\end{array}$} \\
\hline & $\mathbf{n}$ & Rate & $\mathbf{n}$ & Rate & $\mathbf{n}$ & Rate & $\mathbf{n}$ & Rate \\
\hline 1. Agriculture, forestry \& fishing & 22 & 51 & 2 & 739 & 0 & 0 & 0 & 0 \\
\hline 2. Mining \& quarrying & 13 & 131 & 6 & 408 & 5 & 54 & 2 & 136 \\
\hline 3. Food \& organic material manufacture & 109 & 73 & 62 & 416 & 10 & 7 & 0 & 0 \\
\hline 4. Petrochem, rubber, \& plastics manufacture & 58 & 69 & 52 & 320 & 9 & 10 & 18 & 111 \\
\hline 5. Metallic \& automotive products manufacture & 118 & 46 & 58 & 399 & 7 & 3 & 24 & 165 \\
\hline 6. Utilities \& construction & 23 & 11 & 6 & 39 & 8 & 4 & 4 & 26 \\
\hline 7. Health \& social services & 46 & 15 & 70 & 54 & 1 & $<0.5$ & 34 & 26 \\
\hline 8. Other & 128 & 8 & 86 & 66 & 20 & 1 & 20 & 15 \\
\hline 9. Not known* & 43 & - & 14 & - & 3 & - & 6 & - \\
\hline Total & 559 & 20 & 356 & 111 & 63 & 2 & 108 & 34 \\
\hline
\end{tabular}

\section{INHALATION ACCIDENTS}

\section{Incidence}

As the major part of the illnesses caused in this way were reported by occupational physicians, who will have had immediate access to the nature of the inhalation, it is the analysis of their data that is most informative. Those at highest risk were often employed in craft and related jobs, plant and machine work, and associated professional and technical occupations, but also in personal and protective services (table 3). Again, the three industries at highest risk are metallic and automotive products manufacture; mining and quarrying and petrochemical, rubber, and plastics manufacture (table 4). Consideration of the agents responsible helps to clarify the relation.

\section{Agents}

Tables 7 and 8, which show analyses by occupation and industry, analogous to the data shown in tables 5 and 6 for occupational asthma, may be obtained from the authors on request. Although almost as many different agents were reported as by chest physicians for asthma, they are more simply classifiable into five categories, of which irritant gases are the most numerous ( $42 \%)$, followed by solvent vapours ( $18 \%)$, metallic fume ( $11 \%)$, acid mists $(9 \%)$, and other $(18 \%)$. As with asthma, there is evidence

Table 5 Agents reported by chest physicians in occupational asthma, 1992-2001

\begin{tabular}{|c|c|c|c|c|c|c|}
\hline \multirow[b]{2}{*}{ Agent } & \multicolumn{2}{|l|}{$1992-95$} & \multicolumn{2}{|l|}{$1996-2001$} & \multicolumn{2}{|l|}{$1992-2001$} \\
\hline & $\begin{array}{l}\text { Estimated total } \\
\text { reports }\end{array}$ & $\begin{array}{l}\text { Annual average } \\
(\%)\end{array}$ & $\begin{array}{l}\text { Estimated total } \\
\text { reports }\end{array}$ & $\begin{array}{l}\text { Annual average } \\
(\%)\end{array}$ & $\begin{array}{l}\text { Estimated total } \\
\text { reports }\end{array}$ & $\begin{array}{l}\text { Annual average } \\
(\%)\end{array}$ \\
\hline \multicolumn{7}{|l|}{ Organic } \\
\hline Flour/grain & 251 & $63(9)$ & 293 & $49(9)$ & 544 & $54(9)$ \\
\hline Wood dusts & 124 & 31 (4) & 213 & $36(6)$ & 337 & $34(6)$ \\
\hline Solder/colophony & 124 & $31(4)$ & 126 & $21(4)$ & 250 & $25(4)$ \\
\hline Lab animals & 88 & 22 (3) & 77 & $13(2)$ & 165 & $17(3)$ \\
\hline Other animals & 44 & 11 (2) & 98 & $16(3)$ & 142 & $14(2)$ \\
\hline Latex & 21 & $5(1)$ & 110 & $18(3)$ & 131 & $13(2)$ \\
\hline Enzymes & 33 & $8(1)$ & 63 & $11(2)$ & 96 & $10(2)$ \\
\hline Vegetable dusts & 33 & $8(1)$ & 51 & $9(2)$ & 84 & $8(1)$ \\
\hline Fish/crustaceans & 18 & 5 (1) & 51 & $9(2)$ & 69 & 7 (1) \\
\hline Other organic substances & 178 & $45(6)$ & 148 & $25(4)$ & 326 & $33(5)$ \\
\hline Subtotal & 914 & $229(33)$ & 1230 & 205 (37) & 2144 & $214(35)$ \\
\hline \multicolumn{7}{|l|}{ Chemical } \\
\hline Isocyanates & 400 & $100(14)$ & 443 & $74(13)$ & 843 & $84(14)$ \\
\hline Glutaraldehyde & 123 & $31(4)$ & 90 & $15(3)$ & 213 & $21(3)$ \\
\hline Irritant gases & 68 & $17(2)$ & 75 & $13(2)$ & 143 & $14(2)$ \\
\hline Pharmaceuticals & 51 & $13(2)$ & 37 & $6(1)$ & 88 & $9(1)$ \\
\hline Formaldehyde & 30 & $8(1)$ & 34 & $6(1)$ & 64 & $6(1)$ \\
\hline Other specified chemicals & 304 & $76(11)$ & 325 & $54(10)$ & 629 & $63(10)$ \\
\hline Subtotal & 976 & $244(35)$ & 1004 & $167(30)$ & 1980 & 198 (32) \\
\hline \multicolumn{7}{|l|}{ Metallic } \\
\hline Metals/metallic compounds & 128 & $32(5)$ & 146 & $24(4)$ & 274 & $27(4)$ \\
\hline Welding fume, incl steel & 87 & $22(3)$ & 93 & $16(3)$ & 180 & $18(3)$ \\
\hline Subtotal & 215 & $54(8)$ & 239 & 40 (7) & 454 & $45(7)$ \\
\hline \multicolumn{7}{|l|}{ Miscellaneous } \\
\hline Epoxy/other resins & 119 & $30(4)$ & 86 & $14(3)$ & 205 & $21(3)$ \\
\hline Cutting oils/coolants & 75 & $19(3)$ & 50 & $8(1)$ & 125 & $13(2)$ \\
\hline Paints & 65 & $16(2)$ & 41 & $7(1)$ & 106 & $11(2)$ \\
\hline Glues & 74 & $19(3)$ & 29 & 5 (1) & 103 & $10(2)$ \\
\hline Cleaning products & 30 & $8(1)$ & 58 & $10(2)$ & 88 & $9(1)$ \\
\hline Acrylics & 27 & 7 (1) & 39 & $7(1)$ & 66 & 7 (1) \\
\hline Inks & 27 & 7 (1) & 32 & 5 (1) & 59 & 6 (1) \\
\hline Other specified agents & 107 & $27(4)$ & 189 & $32(6)$ & 296 & $30(5)$ \\
\hline Subtotal & 4 & $131(19)$ & 524 & $87(16)$ & 1048 & 105 (17) \\
\hline Unknown/unspecified & 182 & $46(7)$ & 356 & 59 (11) & 538 & 54 (9) \\
\hline Total & 2811 & $703(100)$ & 3353 & $559(100)$ & 6164 & $616(100)$ \\
\hline
\end{tabular}




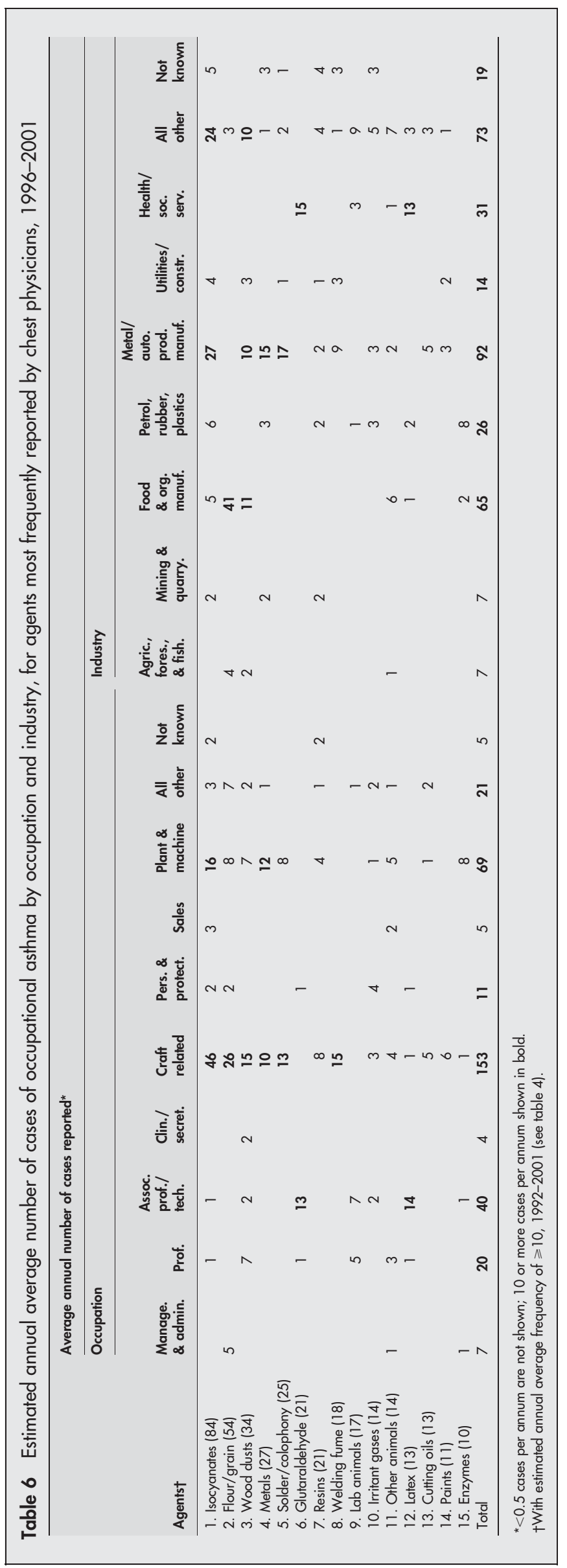

of a similar drop in frequency between 1992-95 and 1996-2001 in irritant gases, metallic fume, and acid mists, but not in solvent vapours or other substances. Irritant gases were most frequently reported in craft related and plant and mechanical occupations; and in the petrol, rubber, and plastics, and health and social services industries (table 8).

\section{ALLERGIC ALVEOLITIS}

Cases of this disease, though far less frequent than initially expected, were reported almost entirely by chest physicians. Most of the cases were in agriculture, forestry, and fisheries, and affected mainly managers (including farm owners), administrators, and associated professional, and technical workers. Of 414 cases in which the suspected agent was specified, $83 \%$ were organic, two thirds bacterial or fungal, and one third, animal. The remaining $17 \%$ were various chemical agents, of which isocyanates were the most prominent.

\section{DISCUSSION}

Reporting schemes inevitably deal with the top of an iceberg, a proportion of which lies beneath the surface, varying considerably with type of disease. In the UK, clinical specialists can report only on patients referred to them, who in turn will usually first have been seen by a general practitioner or occupational physician. Their opinions on diagnosis, causation, and questions of work and exposure will strongly affect decisions on whether and what to report. For example, information about occupation is probably more reliable than industry, about which neither the patient nor chest physician may be sure. This problem may be less for the occupational physician, if only because their patients are usually seen at work and at an earlier stage. None of these questions need detract seriously from the primary purpose of a reporting scheme, provided that a well defined procedure is maintained, and that the top of the iceberg is reasonably representative of what lies beneath. Thus the SWORD data probably give a fairly true picture of new cases of respiratory illness caused by work in the country generally, as do the OPRA data for employees covered by occupational health services.

The substantial difference between incidence rates based on reports from chest and occupational physicians requires some explanation. The latter serve only a minority of the working population, mainly in health and social services, and the larger private enterprises, and seldom see patients over 60 years of age. Although not normally responsible for treatment, they may be the first to make the diagnosis, often at an earlier stage even than the general practitioner. Clinical specialists, on the other hand, are available by referral to the entire population, regardless of age, sex, or location. Their patients are seen less often at an early stage, tend to be more severely ill, and, at least some, for a medicolegal opinion. These factors could well be responsible for the contrasting rates for mesothelioma, benign pleural disease, and lung cancer in table 1 , and most of the large differences by occupation and industry for asthma and inhalation accidents in tables 3 and 4 .

For the primary purpose of surveillance, reporting schemes are clearly useful, but in seeking to understand the basic aetiology and pathogenesis of diseases such as occupational asthma, it is another matter. Whereas population surveys suggest that people with asthmalike symptoms made worse by conditions at work is a common problem of low specificity, SWORD and OPRA findings indicate that although many workers are 


\section{Main messages}

- By far the highest rates of both asthma and inhalation injuries were experienced by machine operatives, and craft related employees in the manufacturing industries.

- In addition there was substantial risk from latex and glutaraldehyde among technical and nursing professionals in the health services.

exposed to a variety of specific sensitisers, the proportion who go on to develop asthma as a result is relatively low. Occupational asthma thus presents two contrasting problems with differing needs. The first, with wide implications for occupational health, calls for research into the prevention of common respiratory consequences of an adverse environment. The second, and less frequent, calls for the identification of personal factors which affect individual vulnerability to specific sensitisers. As workplace exposures are brought under control, behavioural and genetic factors may well become more prominent. ${ }^{8} 9$

As both SWORD and OPRA are wholly dependent on the voluntary reporting of newly diagnosed cases of illness, it is not surprising that total numbers overall and by diagnosis vary from year to year, probably for reasons unrelated to true incidence. Trends in time might therefore be misleading; however, additional evidence is sometimes provided by the proportional distribution of diagnoses and agents. In table 5, for example, although the annual average number of cases of occupational asthma reported was certainly lower in the second six than in the first four years, this was accompanied by a fall in certain agents but not others, adding to the probability that there was a true reduction overall. A detailed analysis made recently for the Health and Safety Executive, using Poisson regression to allow for variation in the number of reporters and their response, concluded that at least for asthma this downward trend probably reflected a real decrease in disease incidence. ${ }^{10}$

Incidence rates based on national denominators are informative, but limited by the more detailed and specific information on cases reported by physicians than is available for the employed population at risk, particularly as regards frequency and intensity of exposure. For example, the high rates of asthma in certain occupations and industries (tables 3 and 4) are wholly dependent on the unknown proportion of employees in each of these segments who are exposed. The same kind of question affects the analysis of agents shown in tables 5 to 8 (tables 7 and 8 available from the authors on request). Thus the relatively low rates for asthma in Health and Social Services (table 4) are probably explained by the large denominator for this section, among whom nurses and technicians may be at high risk, as suggested by table 6 . Greater insight is obtainable if the second and third digits in the SOC and SIC classifications are used, but with several hundred such groups, the tabulations might be unwieldy. More detailed analyses of selected occupations and industries could be made, however, to pinpoint priorities for control.

International comparisons, recently reviewed by Meredith and Blanc ${ }^{11}$ are difficult. SWORD's strengths are also its weaknesses; they depend on the individual judgement of most of the UK's specialist physicians in reporting new illnesses diagnosed in normal clinical practice and judged in their opinion to have been caused by work, together with the agents and occupations thought responsible. There can be no assurance that any general population survey would identify

\section{Policy implications}

- Control of occupational asthma, initiated by specific exposures at work, will require differing strategies for research and control from the more frequent preexisting asthma, made worse by the working environment.

the same cases, or arrive at the same conclusions. Surveys of such populations, on the other hand, are usually concerned with period prevalence, not incidence, and with symptoms, without diagnosis, caused or made worse by work. As causation in these surveys is then a matter of statistical comparison of work histories, rather than clinical opinion, it is impossible to compare the two approaches, though they may provide complementary information.

An example of this difference is afforded by a major survey on the prevalence of asthmatic symptoms, induced or aggravated by work in 16 industrial countries, including the UK, by Kogevinas et al. ${ }^{12}$ The most consistent evidence of risk was found in farmers, agricultural workers, and cleaners. Very similar findings among cleaners and agricultural workers were also reported from a recent analysis of asthmatic symptoms in a national survey among US workers. ${ }^{13}$ Our table 5, however, does not suggest a major role for either "other animals", vegetable dusts, or cleaning products. Moreover, a more detailed analysis of our data for 19922001 gave the annual average incidence of asthma for domestic cleaners (SOC 958) as 13 per million against 38 overall, and only 62 per million for farmers and farm workers (SOC 160 and 900), still far below 10 other occupations, with rates ranging from 123-1464 per million. The probable explanation for these divergent findings may simply lie in the use of incidence rather than prevalence, and of diagnoses made by specialist physicians rather than self-reported symptoms.

\section{ACKNOWLEDGEMENTS}

The SWORD and OPRA surveillance schemes were largely supported by grants from the Health and Safety Executive (UK), and were wholly dependent on voluntary reporting by chest and occupational physicians throughout the UK.

\section{Authors' affiliations}

J C McDonald, C Zekveld, National Heart \& Lung Institute, Imperial College School of Medicine, London, UK

Y Chen, Centre for Occupational and Environmental Health, University of Manchester, Manchester, UK

N M Cherry, Department of Public Health Sciences, University of

Alberta, Edmonton, Canada

Competing interests: none

\section{REFERENCES}

1 Meredith SK, Taylor VM, McDonald JC. Occupational respiratory disease in the United Kingdom 1989: a report to the British Thoracic Society and the Society of Occupational Medicine by the SWORD project group. Brit J Ind Med 1991;48:292-8.

2 Meredith SK, McDonald JC. Work-related respiratory disease in the United Kingdom, 1989-1992. A report on the SWORD project. Occ Med 1994:44:183-9.

3 Cherry NM, Meyer JD, Holt DL, et al. Surveillance of work-related diseases by occupational physicians in the UK: OPRA 1996-99. Occup Med 2000;50:496-503.

4 Office for National Statistics. Labour Force Survey, Winter 1999. London: The Stationery Office, 2000.

5 McDonald JC. The estimated workforce served by occupational physicians in the UK. Occup Med 2002;52:401-6. 
6 Office of Population Censuses and Surveys. Standard Occupational Classification. London: HSMO, 1990.

7 Central Statistical Office. Indexes to the Standard Industrial Classification of Economic Activities 1992. London: HMSO, 1993.

8 Newman Taylor AJ. Genetics and occupational asthma. In: Bernstein IL, Chan-Yeung M, Malo JL, Bernstein DI, eds. Asthma in the workplace. New York: Marcel Dekker, 1999:67-80.

9 Newman Taylor AJ, Cullinan P, Lympany PA, et al. Interaction of HLA phenotype and exposure intensity in sensitisation to complex platinum salts. Am J Resp Crit Care Med 1999; 160:435-8.
10 Cherry NM. Statistical analysis of ODIN, Report to HSE, 2004.

11 Meredith S, Blanc P. Surveillance: clinical and epidemiological perspectives. In: Hendrick D, Burge P, Beckett W, Churg A, eds. Occupational disorders of the lung. London: WB Saunders, 2001.

12 Kogevinas M, Antó JM, Sunyer J, et al. Occupational asthma in Europe and other industrialised areas: a population-based study. Lancet 1999;353:1750-4.

13 Arif AA, Delclos GL, Whitehead LW, et al. Occupational exposures associated with work-related asthma and work-related wheezing among US workers. Am J Ind Med 2003;44:368-76.

\section{Clinical Evidence-Call for contributors}

Clinical Evidence is a regularly updated evidence-based journal available worldwide both as a paper version and on the internet. Clinical Evidence needs to recruit a number of new contributors. Contributors are healthcare professionals or epidemiologists with experience in evidence-based medicine and the ability to write in a concise and structured way.

Areas for which we are currently seeking contributors:

- Pregnancy and childbirth

- Endocrine disorders

- Palliative care

- Tropical diseases

We are also looking for contributors for existing topics. For full details on what these topics are please visit www. clinicalevidence.com/ceweb/contribute/index.jsp

However, we are always looking for others, so do not let this list discourage you.

Being a contributor involves:

- Selecting from a validated, screened search (performed by in-house Information Specialists) epidemiologically sound studies for inclusion.

- Documenting your decisions about which studies to include on an inclusion and exclusion form, which we keep on file.

- Writing the text to a highly structured template (about 1500-3000 words), using evidence from the final studies chosen, within 8-10 weeks of receiving the literature search.

- Working with Clinical Evidence editors to ensure that the final text meets epidemiological and style standards.

- Updating the text every 12 months using any new, sound evidence that becomes available. The Clinical Evidence in-house team will conduct the searches for contributors; your task is simply to filter out high quality studies and incorporate them in the existing text.

If you would like to become a contributor for Clinical Evidence or require more information about what this involves please send your contact details and a copy of your CV, clearly stating the clinical area you are interested in, to CECommissioning@bmigroup.com.

\section{Call for peer reviewers}

Clinical Evidence also needs to recruit a number of new peer reviewers specifically with an interest in the clinical areas stated above, and also others related to general practice. Peer reviewers are healthcare professionals or epidemiologists with experience in evidence-based medicine. As a peer reviewer you would be asked for your views on the clinical relevance, validity, and accessibility of specific topics within the journal, and their usefulness to the intended audience (international generalists and healthcare professionals, possibly with limited statistical knowledge). Topics are usually 1500-3000 words in length and we would ask you to review between 2-5 topics per year. The peer review process takes place throughout the year, and out turnaround time for each review is ideally 10-14 days.

If you are interested in becoming a peer reviewer for Clinical Evidence, please complete the peer review questionnaire at www.clinicalevidence.com/ceweb/contribute/peerreviewer.jsp 